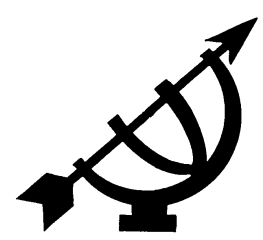

\title{
Waardes in die opvoeding en onderwys: 'n Babelse verwarring
}

\author{
J.A. Rens, J.L. van der Walt \& N.J. Vreken
}

Fakulteit Opvoedingswetenskappe

Potchefstroomkampus

Noordwes-Universiteit

POTCHEFSTROOM

E-pos: soojar@puk.ac.za

jlvdwalt@intekom.co.za

soonjv@puk.ac.za

\begin{abstract}
Values in education and teaching: a Babylonian confusion

Although the debate on values and values-education has been going on for several years, it is evident from literature that there is, as yet, no unanimity on what is meant by the concept "values". This article is an attempt to clarify the confusion between various value-education related concepts and to analyse the phenomenon from an ontological perspective and also to demonstrate that man's choice of terminology depends on presuppositions.
\end{abstract}

This article was written from a reformational perspective, based on the ground motif of the creation, fall, redemption and restoration. From this perspective it is clear that man was created as a value-driven being and that his/her values are guided by religious convictions and a concomitant world view. It is further argued that "principles" and "values" are neither synonymous nor the same. "Principles" are fixed, unchanged points of departure, whereas values emanate from principles and their application is determined by the demands of the contingent situation.

\section{Opsomming}

\section{Waardes in die opvoeding en onderwys: 'n Babelse verwarring}

Alhoewel die debat oor waardes en waarde-opvoeding reeds baie jare aan die gang is, blyk uit die literatuur dat daar nie eenstemmigheid bestaan oor wat presies bedoel word met die 
begrip "waardes" nie. Die outeurs poog om die verwarring wat daar bestaan tussen waarde-opvoedingsverwante begrippe op te klaar, "waardes" vanuit 'n ontologiese hoek te beskryf en om aan te toon dat 'n mens se keuse van die terminologie berus op sekere voorteoretiese aannames.

Die vraagstuk word vanuit 'n reformatoriese denkraamwerk ondersoek, met die motief van skepping, sondeval, verlossing en herstel as uitgangspunt. Op grond hiervan word aangetoon dat die mens as waardewese geskep is en dat sy/haar waardes deur religieuse vertrekpunte en die lewensvisie wat daaruit vloei, gerig en ingekleur word. Verder word ook getoon dat "beginsels" en "waardes" nie dieselfde is nie, maar dat "beginsels" vaste en onveranderlike sake is waaruit die waardes van die mens voortspruit. Dit word grootliks bepaal deur die situasie waarin die mens hom/haar bevind.

\section{Inleiding en probleemstelling}

In die alledaagse omgang word daar dikwels opmerkings gemaak oor waardeverlies, -vervlakking en selfs van 'n waarde-"inploffing". Op akademiese kongresse en in opvoedkundige tydskrifte kom die onderwerp al hoe meer ter sprake (De Klerk, 2005; Abdool \& Vreken, 2005). Tydens die Opvoedkundevereniging van Suid-Afrika se konferensie in 2003 is daar selfs 'n pleidooi deur 'n respondent gelewer vir die instelling van ' $n$ nuwe belangegroep wat oor waardes en waarde-opvoeding moet besin (Vreken, 2004).

Die debat oor waardes en waarde-opvoeding is egter al vir baie jare aan die gang, te oordeel aan wat die literatuur en die internet bied. Dit is egter ook duidelik dat daar nie eenstemmigheid is oor wat presies bedoel word met waardes nie, of watter waardes daar bestaan nie, en of waarde-opvoeding wel moontlik is en, indien wel, presies hoe dit gedoen behoort te word nie. Die huidige onderwysowerheid in Suid-Afrika se dokument oor waardes (DoE, 2001:iv-v) het nie juis gehelp om die verwarring op te klaar nie, maar dit eerder verdiep. Die onderwysowerheid, ander instansies en skrywers oor waardes in die onderwys laat na om te sê presies wat hulle onder waardes verstaan. Omdat hulle dit nie doen nie, praat hulle soms by mekaar verby en/of verstaan mekaar heeltemal verkeerd. Om enkele voorbeelde te noem: Rademeyer (2004:2) omskryf "die gehalte van matrikulante" in terme van die waarde om vakke op hoër graad te neem en deur te kom. Daarteenoor omskryf Krog (2004:11) die gehalte van die onderwys in terme van die waarde dat "leerders in die proses van opvoeding gelei moet word om uitmuntende akademici en unieke denkers te word tot voordeel van 
die gemeenskap". Dit is duidelik dat sy gehalte hier in terme van ander waardes as bloot "die neem van vakke" en "deurkom" sien.

Soms word van waardes gepraat asof hulle eerste sou wees en norme en beginsels, waarvolgens die mens sy/haar lewe inrig, daaruit moet volg. Beckmann en Nieuwenhuis (2004:55) skryf byvoorbeeld:

Omdat die groep belangrikheid toesê aan daardie dinge waaraan waarde geheg word, is dit dan ook moontlik om bepaalde beginsels uit die waardes af te lei wat besluite rig en bepaal hoe die groep sal lewe.

Beller (2002:1) praat eerstens van sosiale waardes wat die werklike lewe weerspieël en bepaal hoe die samelewing die belangrikheid van 'n sosiale karakter beskou - dán eers van "moral values ... as first principles, meaning that they stand by themselves". Sosiale waardes is die positive assets wat deur morele waardes getemper word.

Egan (1990:60) illustreer die waarneming dat begrippe verwarrend gebruik word soos volg:

Belief: I believe that people are free, that they can determine much of what they do.

Value: I prize self-responsibility, both in myself and in my clients.

Norm: I will not make decisions for clients; rather, I will do what I can to help them find their own-solutions to their problems.

Hy sê dat al drie bogenoemde begrippe in die praktyk gebruik word om die betekenis van die begrip waarde te verduidelik. Dit blyk uit bogenoemde dat die begrippe in baie gevalle gebruik word asof hulle dieselfde betekenis sou hê, terwyl daar tog met sorg tussen die begrippe onderskei behoort te word en waarde-opvoedingsverwante begrippe opgeklaar behoort te word.

Waardes en beginsels word ook dikwels as sinonieme gebruik. Halstead en Taylor (2000) beskryf byvoorbeeld waardes as "the principles and fundamental convictions which act as general guidelines to behaviour, the standards by which particular actions are judged to be good or desirable". Hulle noem liefde, gelykheid, vryheid, geregtigheid, geluk, vrede en waarheid as voorbeelde van waardes. Heenan (2002:17) verwys ook na waardes as voorkeure maar in bepaalde gevalle ook as beginsels. 
Covey (1992:35) sê hierteenoor dat waardes nie beginsels is nie. Volgens hom moet beginsels beskou word as universeel en tydloos, terwyl waardes die waarde of prioriteit verteenwoordig wat 'n mens aan dinge, idees of beginsels heg.

Die sentrale teoretiese argument wat in die res van hierdie bespreking gevoer word, is dat hierdie verwarring tussen al die waarde-opvoedingsverwante begrippe opgeklaar moet word en dat aangedui moet word op watter teoretiese en voorteoretiese aannames ' $n$ mens se keuse van begrippe berus. Hierdie doelstelling noodsaak die gebruik van die volgende metodes: Die eerste stap is 'n verheldering van enkele kernbegrippe en die tweede is ' $n$ ontologiese ontleding en beskrywing van die verskynsel waardes. Die derde metode is om aan te toon hoedat 'n mens se keuse van die terminologie op sekere (voor)teoretiese aannames berus.

\section{Reformatoriese vertrekpunt}

Hierdie ondersoek word vanuit 'n reformatoriese denkraamwerk gedoen. Dit impliseer dat die mens sy/haar afhanklikheid van God erken en die Bybel as die enigste bron van waarheid aanvaar. Die denkraamwerk berus op die volgende vier uitgangspunte (Middleton \& Walsh, 1995:19; Wolters, 1992:10):

- dat die mens vrae het oor sy/haar oorsprong (die skepping);

- dat daar iets verkeerd gegaan het met die mensdom (die sondeval);

- dat die mens derhalwe vrae het oor die soeke na 'n oplossing vir die dilemma waarin hy/sy hom/haar bevind (die verlossing); en

- dat die mens vrae het oor die manier waarop daar na die werklikheid gekyk word en dat dit verstaan word vanuit sy/haar lewensvisie (die herstel).

Die kwessie van die vermeende verwarring rondom beginsels en waardes in die onderwys word vanuit hierdie raamwerk benader. Dit is dan veral die laaste van hierdie vier uitgangspunte wat die argument rondom beginsels en waardes gaan rig, aangesien die lewensvisie van die verloste mens die begrippe in die regte perspektief behoort te plaas.

\section{Begripsverheldering}

' $n$ Verheldering van enkele sentrale begrippe soos hulle in hierdie artikel gebruik word, is noodsaaklik om sodoende die verwarring op 
te klaar wat tot dusver rondom waardes in die konteks van waardeopvoeding bestaan. Deur dit te doen word 'n goeie grondslag gelê vir die res van die bespreking.

\section{- Beginsel}

In die Grieks (archê) sowel as in Latyn (principium) het die woord beginsel drie kernbetekenisse, naamlik begin (of oorsprong), leiding (dit wat lei of bepaal), en laastens ryk of gebied (beperk tot 'n bepaalde gebied of geldend vir 'n bepaalde terrein) (Stoker, 1961:32, 33). Volgens die New Oxford Thesaurus of English (Patrick, 2000:1038) dui beginsel (principle) onder andere ook op die volgende: "truth proposition, idea, theory, assumption, basis, fundamental, essence". In die hieropvolgende uiteensetting word met beginsel die volgende bedoel: 'n beginsel is die vaste, onveranderlike uitgangspunt of vertrekpunt wat die mens in al sy doen en late lei en rig.

\section{- Norm}

Die begrip norm word gebruik met die betekenis van maatstaf, om te meet of te beoordeel en daarom is die begrip sinoniem met kriterium. Hierdie begrip dui op die betekenis wat 'n sekere saak het, dit wil sê die waarde van 'n bepaalde saak (Van Rensburg \& Landman, 1992:136). 'n Norm is dus die maatstaf wat die mens gebruik in die handeling of proses van waarde-gee aan iets.

\section{- Lewensvisie}

Volgens Van Rensburg en Landman (1992:114) dui lewensbeskouing op vrae na die dieper sin en betekenis, die doel en waarde van die lewe - en die antwoorde hierop is verskillend vir verskillende mense. Lewensbeskouing dui op iets wat besondere rigting gee aan die opvoedingsgebeure sowel as aan voorwetenskaplike en na-wetenskaplike gebeure. Van der Walt (1999b: 47) maak gebruik van die verbandhoudende woord lewensvisie en gee die volgende definisie daarvoor:

'n Lewensvisie is geïntegreerde, interpreterende, normatiewe geloofperspektiewe op die werklikheid wat menslike aktiwiteite grond, vorm, motiveer, daaraan rigting en sin gee en so die mens se roeping in die wêreld uitspel.

Hierdie definisie is in die res van hierdie besinning van toepassing.

- Religie 
Die begrip religie is afgelei uit die Latynse voorvoegsel re- en die woord ligare. Laasgenoemde beteken om te bind. Die begrip religie dui derhalwe op herbinding of terugbinding (Van der Walt \& Dekker, 1983:2; Collins, 1999). Religie is die terugbinding van die hart van die mens aan God of aan 'n afgod. Volgens Van Rensburg en Landman (1992:189) is religiositeit een van die grondvorme van menswees. Daar word verderaan met hierdie omskrywing van religie gewerk.

\section{- Waarde}

Die begrip waarde is ontleen aan die Latynse woord valere wat beteken "om sterk en kragtig te wees". Volgens die Handwoordeboek van die Afrikaanse Taal (Odendal, 1994:1257) dui waarde op die volgende: "hoedanigheid wat iets wenslik of nuttig maak; betekenis deur gehalte, 'n bedrag waarmee iets betaal word of 'n geldigheid, krag, betekenis." Die Oxford Advanced Learner's Dictionary of Current English (Crowther, 1995:1319) definieer die begrip waarde (value) soos volg: "the quality of being useful or important, or moral or professional standards of behaviour". Die New Oxford Thesaurus of English (Patrick, 2000:1038) gee die volgende woorde of sinsnedes as sinonieme vir die begrip waarde: "moral principles, ethics, moral code, moral values, standards, moral standards, code of behaviour, rules of conduct, standards of behaviour". (Hierdie is ook 'n voorbeeld waar waarde en beginsel as sinonieme gebruik word.)

Volgens die Psigologiese Woordeboek (Gouws et al., 1982: 329) dui waarde op 'n gesindheid waardeur 'n persoon of 'n groep se voorkeure en gedrag gerig word, en die mate van voortreflikheid, bruikbaarheid of deugde wat aan 'n objek of persoon toegeskryf word.

Dit is duidelik dat die begrip waarde hoofsaaklik twee verskillende dinge kan beteken, naamlik die waarde van 'n item soos 'n motorvoertuig, 'n huis of die kwaliteit of die bruikbaarheid daarvan en ' $n$ waarde, soos byvoorbeeld die houding en gesindheid waarmee 'n persoon se gedrag gerig word. Vir die doel van hierdie artikel word met laasgenoemde betekenis gewerk, omdat die opvoeder (onderwyser) werk met houdings en gesindhede van mense.

\section{Waardes - 'n ontologiese analise}

'n Ontologiese ontleding van waardes is onvolledig sonder 'n kort besinning oor die mens as waardewese. Vanuit 'n reformatoriese 
denkraamwerk word die mens gesien as skepsel van God met 'n bepaalde doel, bestemming en verantwoordelikheid om in die skepping na te kom (Gen. 3:15). Die mens is deur God as die hoof (die kroon, die rentmeester, die stadhouer) van die hele skepping aangestel om met Hom mee te werk aan die verdere ontplooiing daarvan. Die ontplooiing geskied deur kultuurbeoefening, waaronder die beoefening van die wetenskap en die ontwikkeling van tegnologie. Hierdie handelinge van die mens moet in verantwoordelikheid teenoor God en die medemens en in diens van God en die medemens uitgevoer word (Van der Walt, 1999a:7, 8). Verantwoordelikheid in hierdie sin dui letterlik op antwoord gee of respondeer op die mens se roeping deur God. Wanneer die mens só antwoord, doen hy dit aan die hand van riglyne. Daar is vir die mens verskillende soorte riglyne wat sy/haar optrede rig, waaronder beginsels (eerste uitgangspunte en vertrekpunte), waardes (as uitdrukkings van dit wat vir die mens waardevol is) en norme (uitdrukkings van die maatstawwe wat die mens in sy lewe en op sy gedrag toepas).

Die reformatoriese uitgangspunt dat God die mens as 'n waardewese geskep het, het belangrike implikasies vir die opvoeding en onderwys. Opvoeding is ' $n$ proses of handeling waarmee minder volwasse mense (gewoonlik kinders) toegerus word met die vermoë om God en die medemens in verantwoordelikheid te dien, en om hulle godgegewe opdrag in die skepping uit te voer. Opvoeders moet hulle dus daarop toelê om die opvoedeling se potensiaal om te ontwikkel tot ' $n$ volwasse en verantwoordelike waardewese te laat ontplooi.

Om waarde as ontiese verskynsel te begryp, is dit nodig om die waardeverskynsel uit verskeie hoeke te ondersoek. Die mens is in sy wese ingestel op waardes; hy/sy takseer die werklikheid waarmee hy/sy daagliks te doen kry aan die hand van sekere waardes. Waardes het bepaalde kenmerke soos die volgende:

\section{- Waardes word bepaal deur die mens se lewensvisie}

Waardes het met lewensvisie te doen aangesien waardes met die mens en sy lewe verband hou. Die mens is die enigste wese wat oor 'n lewensvisie beskik. 'n Lewensvisie is volgens Van der Walt (1999b:49) 'n ordelike samehang van oortuigings wat as eenheid funksioneer om vir die mens rigting te gee. Waardes het te doen met oortuigings en daarom kan 'n mens met reg sê dat waardes ook met lewensvisie verband hou. Die begripsomskrywing van lewensvisie maak dit duidelik dat 'n mens se waarde-oriëntering voortvloei uit 
sy/haar lewensvisie. Die uitlewing van 'n mens se waardes is 'n weerspieëling van so 'n persoon se lewensvisie. Die lewensvisie sluit idees oor God, die werklikheid of die skepping en die mens in en daarom vergestalt dit in die waardes wat 'n individu aanhang.

Volgens Van der Walt (1999a:7, 8) gee ontologiese veronderstellings verdere riglyne in die gesprek oor waardes. God is die wetgewer en in sy soewereiniteit gee $\mathrm{Hy}$ die wette vir die hele skepping. Hy regeer oor alles wat Hy geskep het deur hierdie wette. Die mens is ook deur God geskep en moet soos alle ander geskape dinge aan die wette van God gehoorsaam wees. Van der Walt (1999a:24-25) stel verder dat die Woord van God sy wil (wet) vir die skepping bevat. In God se wet word die mens beveel om in alles sy naaste lief te hê. Dus, die opdrag van God is saamgevat in die sentrale liefdesgebod van liefde tot God en tot die naaste (Matt. 22:36-40). Die mens se antwoord daarop word in die eerste plek gerealiseer in die vorm van beginsels vir die verskillende terreine waarop die mens hom/haar bevind, soos byvoorbeeld trou, sorg, rentmeesterskap en geregtigheid. In die tweede plek voer die mens 'n lewe wat hierdie beginsels vergestalt in die vorm van die waardes wat hy/sy verwerklik, deur in ooreenstemming met beginsels te lewe.

Die mens is ' $n$ religieuse wese - dit beteken dat alle mense in 'n afhanklikheidsverhouding staan teenoor iets wat hulle as goddelik of transendent beskou. Vir die Christen is die religieuse verhouding tot die God van die Bybel totaal (dit omvat die hele lewe), sentraal (in alles wat die mens doen is sy/haar diepste wese by betrokke) en integraal (die binding van die mens se hart moet geïntegreerd wees met alles wat hy/sy doen) (Van der Walt, 1999(b):334).

Fowler et al. (1990:52; vgl. Gousmett, 1996) meen “... educational values are grounded in life values developed in the context of a world view at the heart of which is a religious commitment of one kind or another". Hulle oordeel ook dat waardes nie gevorm word deur die een of ander objektiewe proses waar die religieuse vrae uitgesluit is nie, maar dat waardes gevorm word in konteks met die lewensvisie wat die mens aanhang en wat spruit uit die religieuse oortuigings (commitment - eksistensiële verbintenis) van daardie mens (Fowler et al., 1990:53). Die religieuse vorm die kern/ oorsprong vir die samehang van waardes vir die mens (Badenhorst, 1992:1). Die hoogste modaliteit van die mens is die pistiese, die een wat al die ander "stempel" of "inkleur". Dieselfde geld vir die waardes wat in die onderskeie modaliteite van die werklikheid gestalte kry (Hattingh, 1991:94). Dus, die religieuse commitment of 
verbintenis stempel of bepaal alle waardes wat 'n persoon mag huldig.

\section{- Waardes het te doen met oortuigings}

Dit is alreeds gemeld dat waardes (en beginsels) voortvloei uit die oortuigings van die mens. Tyree et al. (1997) beskryf waardes as:

opinions about the desirability or importance or rightness of something. The 'something' may be objects, events, people's actions, policies, processes, or ideas. Formulated statements relating to values tell whether something is good or bad, better or worse, well done or poorly done, suitable or unsuitable.

Dit is dus duidelik dat waardes tot uiting kom deur mense se oortuigings aangaande dinge in die werklikheid (ten opsigte van ander mense, dinge of gebeure) (Hattingh, 1991:93) en verder dui dit op die mate van belangrikheid van daardie spesifieke iets vir die mens.

Rokeach (1973:5) beskryf waarde as:

... an enduring belief that a specific mode of conduct or endstate of existence is personally or socially preferable to an opposite or converse mode of conduct or end-state of existence. A value system is an enduring organization of beliefs concerning preferable modes of conduct or end-states of existence along a continuum of relative importance.

Hier word waardes dus gekoppel aan die oortuigings (beliefs) wat die mens se gedrag bepaal. Waardes help die mens om oor sy gedrag te besluit in terme van persoonlike en sosiale oogmerke, soos eensgesindheid en vrede in die samelewing en verder ook ten aansien van morele gedrag (bv. eerlikheid).

Oortuigings is uitgangspunte wat kan wissel van die sogenaamde feitelike (ek glo dat om vars vrugte en groente te eet jou gesondheid kan verbeter) tot die intiem-persoonlike (ek glo dat ek suksesvol in my lewe gaan wees). Oortuigings word dikwels deur houdings versterk en gee betekenis aan die ervarings in die mens se lewe (Collings, 1996:3). Rossouw (1996) meen dat waardes as oortuigings gesien kan word as hy sê dat waardes relatief stabiele oortuigings is van dit wat belangrik is vir alle mense.

\section{- Waardes is persoonlik}

Waardes word net op personale vlak aangetref. As waardewese word die mens met die potensiaal tot 'n waardebewussyn gebore en 
nie met waardes as sodanig nie (Hattingh, 1991:94). Slegs die mens het die persoonlike vermoë om onder andere deur die begeleiding van ander mense 'n waardebewussyn te ontwikkel. Waardes is verder persoonlik daarin dat hulle 'n bydrae lewer tot die sin van elke mens se lewe. Beck (1990:2) bring waardes in verband met human well-being - dus, dinge wat die menslike bestaan die moeite werd maak, soos geluk, vrede, gesondheid, vervulling, vryheid, om ander te help, 'n gesondheidsbevorderende omgewing en so meer.

Waardes het ook te doen met die wyse wat die mens oor sekere dinge voel en wat sy/haar houding daaroor is. Baie van die mens se houdings word deur dit wat vir die samelewing aanvaarbaar is bepaal, sowel as deur die individu se persoonlike geaardheid en geskiedenis. Waardes besit dus ook gemoedsgesteldhede, omdat die individu of groep 'n sterk gevoel daaroor openbaar (Hattingh, 1991:93). Die mens hoef homself/haarself nie altyd verbaal uit te spreek oor sy/haar waardes nie - waardes blyk soms uit nie-verbale optrede. Waardes is dus nie altyd direk waarneembaar nie en is bewus of onbewus van aard, verbaal of nie-verbaal.

Waardes word in 'n waardesisteem op 'n kontinuum van belangrik na minder belangrik gerangskik en wissel van dié waaraan 'n hoër prioriteit verleen word tot dié waaraan 'n laer prioriteit verleen word (Hattingh, 1991:94). Omdat so 'n waardesisteem 'n bepaalde rangorde van waardes bevat, beteken dit dat waardesisteme van individu tot individu mag verskil omdat waardes so persoonlik is. Dit is juis hierdie rangorde van waardes wat soms nie in ag geneem word nie. Die Waardemanifes van die Suid-Afrikaanse onderwysowerheid is 'n voorbeeld hiervan: slegs waardes is gekies (soos geformuleer in die Grondwet en die Handves op Menseregte van Suid-Afrika) wat duidelik gerig is op die bevordering van die nasionale waardes van nasiebou en demokrasie (James, 2000:6).

\section{- Waardes het 'n universele karakter}

Waardes dra 'n universele karakter, aangesien sekere waardes, soos verhoudingswaardes, universeel voorkom. Heenan (2002:33) sê tereg "each cornerstone value is consistent, universal and transcultural". Hy gaan van die standpunt uit dat daar 'n "core of universal moral values and precepts" is (Heenan, 2000). Selfs aan sulke universele waardes gee elke groep en individu 'n eie betekenis (Hattingh, 1991:95). Eerlikheid, verantwoordelikheid en integriteit kan byvoorbeeld waardes wees wat wêreldwyd hoog geskat word, maar hulle is nie absoluut nie, vloei steeds uit religieuse voorververonderstellings of aannames voort en kry slegs 
in daardie konteks betekenis (Gousmett, 1996). Die tekortkoming in die redenasie ten gunste van universele waardes is dat daar nie aandag gegee word aan die hele tipologie van waardes soos Hattingh (1991:200-209) dit beskryf nie, maar slegs aan enkele waardes. ' $n$ Voorbeeld hiervan is die veiligheidswaarde, wat dui op die veilige voortbestaan van die mens. Hieraan word min aandag gegee, terwyl 'n waarde soos die morele, wat dui op die sedelike, weer baie aandag geniet.

\section{- Waardes is subjektief, maar kan ook objektief wees}

Om waardes as subjektief te beskryf, sluit baie nou aan by die waarneming dat waardes persoonlik van aard is. Collings (1996: 12, 13) beskryf ' $n$ waarde as iets wat die mens persoonlik ervaar of die manier hoe iets volgens die individu behoort te wees indien ons in 'n ideale wêreld sou lewe. As iemand dus 'n waarde-oordeel maak, maak die persoon 'n subjektiewe vergelyking, waar die een ding bo 'n ander geplaas word, volgens sy/haar persoonlike waardevoorkeure.

Waardes dien as subjektiewe kriteria vir die mens se evaluering en beoordeling van sy/haar medemens, objekte, situasies en handelinge. Hierdie waardes word verder beïnvloed deur die eise van die situasie waarin die mens hom bevind. Die subjektiewe waardeprioriteite van die mens word dus deur sy situasie beïnvloed en bepaal, en dit beïnvloed weer die mens se waarde-oriëntasies (Hattingh,1991:94).

Waardes kan tegelyk objektief en subjektief van aard wees: objektief in die sin dat waardes onafhanklik van mense en hul besluite kan bestaan; subjektief in die opsig dat waardes persoonlike besluite, keuses en belewings weerspieël (Hattingh,1991:95). 'n Voorbeeld van objektiewe waardes is eerlikheid en verantwoordelikheid as waardes wat deur 'n objektiewe mening van alle mense aanvaar word. Objektiewe waardes is dus waardes wat tipies wêreldwyd deur mense as reg aanvaar word, terwyl die persoonlike, subjektiewe idees van die individu nie noodwendig dieselfde status het nie.

Heenan (2002:17) onderskei tussen waardes as voorkeure en waardes as beginsels. ${ }^{1}$ Voorkeur-waardes sluit aan by die situasie-

$1 \quad H i e r$ is nog 'n voorbeeld van terminologiese verwarring. Dit is duidelik dat Heenan die begrippe waardes en beginsels verwarrend gebruik, want waardes kan nie as beginsels beskou word nie; waardes word gerig deur beginsels wat 
etiek, want waardes word dan gerelativeer deur stellings te maak soos "My values are as good as yours". Waardes is dan subjektief en "something to have". Heenan (2002:18) beweer egter dat sekere waardes as beginsels wel objektief is en "something to be". Hierdie uitgangspunt is gegrond op die veronderstelling of aanname dat daar universele waardes is, soos eerlikheid, bedagsaamheid en respek.

\section{- Waardes is rigtinggewend}

Waardes dien as riglyne vir die mens se gedrag en hulle beïnvloed en bepaal die besluite wat hy/sy neem en dus sy/haar gedrag, en hulle dien ook as basis vir individuele en kollektiewe optredes. Waardes skryf nie noodwendig gedrag voor nie, maar bied riglyne oor wat as wenslik, goed, reg en aanvaarbaar in sekere situasies en omgewings beskou kan word (Moller, 1992:4).

Pilch en Malina (1993:xiii) versterk hierdie gedagte met hulle siening dat waardes die kwaliteit en koers beskryf wat verwag word om te vergestalt in die gedrag van die individu. 'n Waarde is dus 'n algemene, normatiewe oriëntering van gedrag binne 'n sosiale struktuur wat emosioneel geanker is in die soeke en ondersteuning van die optrede van die mens. Waardes speel ook 'n rol in die besluite wat mense neem oor die sin, rigting en betekenis van hulle bestaan. Dit sluit nóú aan by wat bespreek is, naamlik dat waardes verband hou met die lewensvisie van die individu, omdat waardes en lewensvisie albei rigtinggewend is.

\section{- Waardes is ideale}

Waardes is ideale, omdat hulle sienings vergestalt oor die werklikheid en daarmee saam ' $n$ ideaal verteenwoordig van hoe die mens graag wil wees (Moller, 1992:4). Moller is verder van mening dat waardes soos prestasies, vryheid en demokrasie idees of sienswyses is wat deur mense gedeel word oor wat goed en sleg, reg en verkeerd, aanvaarbaar en onaanvaarbaar, wenslik en ongewens is en hoe dinge behoort te wees. Waardes het ten nouste te make met norme en maatstawwe vir optrede of gedrag.

Gorman (1974:365) stel 'n aantal vrae waarmee hy aandui hoe waardes verband hou met dit wat vir 'n persoon belangrik is. Hy vra byvoorbeeld:

dui op 'n oorsprong of uitgangspunt. In die lig van die definisies van waardes en beginsels sou dit beter wees as Heenan eerder van die subjektiewe en objektiewe waardes praat, en nie van waardes en beginsels nie. 
Hoe belangrik is die geniet van musiek en kuns in jou lewe?, Wat is jou opinie oor die werk van die humanitêre groep soos die 'Peace Corps'?, Watter plek neem 'n Opperwese in jou lewe in?, Wat dink jy van mense wat finansiële gewin voor eerlikheid en integriteit plaas?

Volgens hom het al hierdie vrae te doen met die relatiewe belangrikheid wat die mens gee aan ideale, mense, aspekte van die lewe en gedrag. ' $n$ Waarde bepaal dus hoeveel betekenis die mens heg aan voorgenoemde aspekte om 'n betekenisvolle lewe te kan lei.

\section{- Waardes het 'n multi-dimensionele samestelling}

Daar kan van 'n tipologie van waardes gepraat word, aldus Hattingh (1991:93). Daar is 'n vergelyking te tref tussen die modaliteite van die mens wat deur Dooyeweerd (1969:38-39) verwoord is, en die genoemde tipologie van waardes. Albei het te doen met die multidimensionaliteit van die mens, wat aan elke modaliteit of funksieveld van sy of haar lewe 'n bepaalde waarde heg. Dit is juis hierdie kenmerk van waardes wat die grootse verwarring veroorsaak ten opsigte van die gebruik van die begrip waarde, omdat mense soms net een van die dimensies of modaliteite van die mens, soos byvoorbeeld die morele, in die waarde-gesprek wil gebruik. Wat egter van belang is, is dat die mens oor 'n bepaalde waardeoriëntasie beskik. Die modaliteite van menswees is in 'n bepaalde rangorde van kompleksiteit gerangskik (Van der Walt \& Dekker, 1983:81-82) - hierdie rangorde bepaal ook die tipologie en samestelling van die waardes wat gehuldig word (Hattingh, 1991:94). Die konkrete situasie waarin 'n betrokke individu hom/haar bevind, bepaal egter die prioriteit by die toepassing van bepaalde waardes in hierdie universele rangorde van modaliteite en geassosieerde waardes.

Die situasie-bepaaldheid van hierdie multi-dimensionele eienskap van die mens se waardes sluit aan by die gedagte dat waardes bepalend is in die besluitnemingsproses.

\section{- Waardes is bepalend in die besluitnemingsproses}

Egan (1990: 60) beskou waardes nie bloot as ideale nie, maar ook as 'n stel kriteria vir besluitneming. Vir Inlow (1972:2) is waardes bepalende faktore wat die mens se keuses in die lewe beïnvloed en daarom sy gedrag bepaal. Hattingh (1991:93) sluit hierby aan: waardes is voorkeurgesindhede wat uitdrukking gee aan wat 
begeerlik, wenslik, verkieslik, betekenisvol en waardevol is. Waardes is mede-beïnvloedend en mede-bepalend van mense se behoeftes, houdings, belangstellings, keuses, wilskrag, selfbeeld, denke, persepsies en die beslissings wat hulle daaroor neem. Behoeftes is veral mede-bepalend vir waardes (Hattingh, 1991:95).

Die mens kies altyd wat vir hom/haar op 'n gegewe oomblik, op 'n bepaalde plek en onder sekere omstandighede die hoogste waarde het. Wanneer hy/sy gekies het, hang die uitvoering daarvan af van sy/haar keuse om gehoorsaam te wees aan die eise van waardes in 'n rangorde van voorkeur - dit hang ten nouste saam met sy/haar lewensvisie (Du Plooy et al., 1985:332-333). Al die waardes wat Hattingh in haar tipologie noem, speel op die een of ander tyd ' $n$ rol by besluitneming.

\section{- Waardes word deur kultuur beïnvloed}

'n Individu se waardes (waarde-oriëntering) word medebepaal deur sy/haar kultuur (etnies, volk, geslag, taal, ensovoorts). Die mens se waardes is dus kultuurgedrewe (Inlow, 1972:2) en die individu kan hom/haar moeilik distansieer van die invloed wat kultuur op sy waardes het. Dit beteken egter nie dat hy/sy hom ten volle daarmee hoef te vereenselwig nie. Indien hy/sy hom-/haarself nie met sy kultuur vereenselwig nie, kan daar konflik in hom-/haarself ontstaan of hy/sy kan in konflik kom met sy kultuurgroep (Hattingh, 1991:95). Kluckhorn (1951:86) ondersteun hierdie siening met 'n stelling wat hy al in 1951 gemaak het, naamlik dat "each distinctive culture has its own values and the essential core of culture consists of traditional ideas and their attached values". Etniese groepe interpreteer en evalueer waardes verskillend (Moller, 1992:4). Omdat kultuur en die waardes wat uit kultuurgebondenheid vloei van groep tot groep kan verskil, kan waardes ook tot konflik tussen verskillende kulture en etniese groeperings aanleiding gee.

\section{Gevolgtrekking en samevatting}

Dit blyk dat sommige mense waardes verwar met beginsels, omdat albei te doen het met die mens se basiese oortuigings aangaande die lewe. Mense redeneer gewoonlik nie oor beginsels nie, maar oefen 'n bewustelike en oorwoë keuse uit oor die waardes wat hulle huldig en toepas. Beginsels sou in 'n sekere sin beskou kon word as die religieuse waardes wat 'n mens huldig. Waardes is ook nie die ontstaanspunt vir 'n mens se beginsels nie; die teendeel is eerder die geval. Die mens se beginsels rig sy/haar waardes. Die religieuse verbintenis (commitment) van die mens vorm die uitgangspunt van 
al die waardes wat gehuldig word. Die lewensvisie word deur die individu se religie gerig en die waardes wat die persoon aanhang word ook daardeur beînvloed. Alle waardes wat die mens huldig en onderhou ten opsigte van die verskillende lewensterreine, byvoorbeeld die ekonomiese, nasionale of ontspanningswaardes word deur die religieuse bepaal en gekleur.

Die kerngevolgtrekking is dat God die mens as waardewese geskep het met die moontlikheid (potensiaal) om waardes te skep en waardes in 'n rangorde van belangrikheid of wenslikheid te plaas. Hierdie feit plaas opvoeders voor 'n groot verantwoordelikheid ten aansien van die ontplooiing van die opvoedeling se potensiaal tot die maak van waardekeuses en -besluite.

\section{Geraadpleegde bronne}

ABDOOL, A. \& VREKEN, N. 2005. Waardeopvoeding vir veranderde skole in Suid-Afrika. Referaat gelewer tydens OVSA-kongres te Potchefstroom, 1214 Januarie 2005.

BADENHORST, D.C. 1992. The limitations and possibilities of the South African education system in the inculcation of values. Scriptura, 41:1-12.

BECK, C. 1990. Better schools: a values perspective. New York: Falmer.

BECKMANN, J. \& NIEUWENHUIS, J. 2004. Die onderwysmanifes oor waardes en demokrasie in die onderwys: 'n fundering en flirtasie met waardes? South African Journal of Education, 24(1):55-63.

BELLER, J. 2002. Positive character development in school sport programs. Washington: ERIC clearinghouse on Teaching and Teacher Education.

COLLINGS, L., ed. 1996. Mindpower - take control of your life. Amsterdam: Life-time books.

COLLINS. Collins concise dictionary. 1999. Glasgow: HarperCollins.

COVEY, S.R. 1992. The seven habits of highly effective people. London: Simon \& Schuster.

CROWTHER, J., ed. 1995. Oxford advanced learner's dictionary of current English. 5th ed. Oxford: Oxford University Press.

DE KLERK, J. 2005. Karakteropvoeding as 'n voorvereiste vir doeltreffende onderrig. Referaat gelewer tydens OVSA-kongres te Potchefstroom, 12-14 Januarie 2005.

DEPARTMENT OF EDUCATION 2001. Manifesto on values, education and DoE democracy. Pretoria: Department of Education.

$$
\text { See DEPARTMENT OF EDUCATION }
$$

DOOYEWEERD, H. 1969. A new critique of theoretical thought. Vol. I-II. Philadephia: Presbyterian \& Reformed Publishing.

DU PLOOY, J.L., GRIESSEL, G.A.J. \& OBERHOLZER, M.O. 1985. Fundamentele pedagogiek vir gevorderde studente. Pretoria: HAUM.

EGAN, G. 1990. The skilled helper - a systematic approach to effective helping. Pacific Grove: Brooks/Cole. 
FOWLER, S., VAN BRUMMELEN, H.W. \& VAN DYK, J. 1990. Christian schooling: education for freedom. Potchefstroom: IRS. (Instituut vir Reformatoriese Studies, Studiestuk 39.)

GORMAN, R.M. 1974. The psychology of classroom learning. Ohio: Merrill.

GOUSMETT, C. 1996. "Cornerstone values" - a critical review from a Christian perspective. http://homepage.ihug.ca.nz/ faithact/study.htm Date of access: 6 Oct. 2004.

GOUWS, L.A., LOUW, D.D., MEYER, D.F. \& PLUG, C. 1982. Psigologiese woordeboek. Eerste uitgawe. Johannesburg: McGraw-Hill.

HALSTEAD, J. \& TAYLOR, M. 2000. Learning and teaching about values: a review of recent research. Cambridge Journal of Education, 30(2):169223, Jun. (In EBSCOHost: Academic Search Elite, Full display: http://www-sa.ebsco.com Date of access: 6 Sept. 2000.)

HATTINGH, L. 1991. 'n Teorie van waardes. Johannesburg: Randse Afrikaanse Universiteit. (D.Ed.-proefskrif.)

HEENAN, J. 2000. Making sense of values. The New Zealand Foundation for Values in Education. http://www.es.co.nz/ cstone/sense.htm Date of access: 5 Sept.2000.

HEENAN, J. 2002. Building character through cornerstone values. Invercargill: The New Zealand Foundation for Values in Education.

INLOW, G.M. 1972. Values in transition - a handbook. New York: Wiley.

JAMES, W., ed. 2000. Values, education and democracy: report of the working group on values in education. Pretoria: Department of Education.

KLUCKHORN, C. 1951. The study of culture in the political sciences. Toronto: Stanford University Press.

KROG, A. 2004. Soektog na onderrig van hoë gehalte. Die Burger: 11, Maart.

MIDDLETON, J.R. \& WALSH, B.J. 1995. Truth is stranger than it used to be Biblical faith in a postmodern age. Downers Grove: InterVarsity.

MOLLER, P.H. 1992. Multi-kulturalisme. Ongepubliseerde besprekingsdokument. Potchefstroom.

ODENDAL, F.F., red. 1994. Verklarende handwoordeboek van die Afrikaanse taal. Midrand: Perskor.

PATRICK, H., ed. 2000. The new Oxford thesaurus of English. Oxford: Oxford University Press.

PILCH, J.J. \& MALINA, B.J. 1993. Biblical social values and their meaning: a handbook. Peabody: Hendrickson.

RADEMEYER, A. 2004. Gehalte van matrikulante "nie in oogwenk verbeter". Die Burger: 24, 2 Sept.

ROKEACH, M. 1973. The nature of human values. New York: Free Press.

ROSSOUW, D. 1996. Waardes wat werk. http://general.rau.ac.za/aambeeld/ november1996/waardes.htm Datum van gebruik: 26 Sept. 2002.

STOKER, H.G. 1961. Beginsels en metodes in die wetenskap. Potchefstroom: Pro Rege Pers.

TYREE, C., VANCE, M. \& McJUNKIN, M. 1997. Teaching values to promote a more caring world - a moral dilemma for the 21st century. Journal for a Just \& Caring Education, 3(2):215-227. (In EBSCOHost: Academic Search Elite, Full display: http://www-sa.ebsco.com Date of access: 27 Jul. 2000.)

VAN DER WALT, B.J. 1999a. Die oorsprong van ons waardekrisis en hoe ons weer duidelike, positiewe Christelike waardes kan terugvind. Potchefstroom: IRS. (Instituut vir Reformatoriese Studies, Studiestuk 381.) 
VAN DER WALT, B.J. 1999b. Visie op die werklikheid - die bevrydende krag van 'n Christelike lewensbeskouing en filosofie. Potchefstroom: IRS. (Instituut vir Reformatoriese Studie, Versamelwerke: Reeks F3.)

VAN DER WALT, J.L. \& DEKKER, E.I. 1983. Fundamentele opvoedkunde vir onderwysstudente. Silverton: Promedia.

VAN RENSBURG, C.J.J. \& LANDMAN, W.A. 1992. Fundamenteel-pedagogiese begripsverklaringe/Notes on fundamental-pedagogic concepts. Pretoria: N.G. Kerkboekhandel.

VREKEN, N.J. 2004. Persoonlike mededeling.

WOLTERS, A.M. 1992. Die skepping herwin - Bybelse grondslae vir 'n reformatoriese lewensbeskouing. Potchefstroom: IRS. (Instituut vir Reformatoriese Studies, Studiestuk 52.)

\section{Kernbegrippe:}

beginsels vanuit 'n Bybelse perspektief

norme

waardes in opvoeding

\section{Key concepts:}

norms

principles from a Biblical perspective

values in education 
